\title{
Sequential determination of calcium distribution in B cells at the various phases of glucose-induced insulin secretion
}

\author{
J.J.Gagliardino, M.C. Semino, O. R. Rebolledo, C. L. Gómez Dumm and R. E. Hernández \\ Experimental and Applied Centre of Endocrinology CENEXA (UNLP-CONICET) and Institute of Embryology, Biology and Histology, \\ Faculty of Medical Sciences, Universidad Nacional de La Plata, La Plata, Argentina
}

\begin{abstract}
Summary. Localization and quantification of calcium pyroantimonate precipitates within the B cells, and determination of insulin secretion were performed in rat pancreas perfused with 3.3 and $16.6 \mathrm{mmol} / 1$ glucose. Observations were carried out during the peak, the refractory period, and at 10 and $20 \mathrm{~min}$ in the second phase of glucose secretion after the start of a glucose challenge. Specific calcium pyroantimonate precipitates, assessed by EGTA cross-incubation, appeared attached to plasma membrane, Golgi complex, mitochondria, cytoplasmic matrix and secretory granules. The total number of cellular calcium pyroantimonate precipitates increased with perfusion time, being significantly higher at every timepoint with the higher concentration of glucose $(16.6 \mathrm{mmol} / \mathrm{l})$ than with the $3.3 \mathrm{mmol} / 1$ glucose concentration. Calcium
\end{abstract}

pyroantimonate precipitates showed a progressive increment both in plasma membranes and mitochondria. In the cytoplasmic matrix, B granules and Golgi complex, a sharp increase in the number of precipitates was detected at the refractory period, followed by a continuous decrease until the end of the experiment. These results show that the number of calcium pyroantimonate precipitates, localized in different organelles, changes according to the functional state of B cells. They stress the importance of intracellular readily exchangeable pools as regulators of calcium availability for insulin stimulus-secretion coupling.

Key words: Insulin secretion, B cell ultrastructure, calcium distribution, pyroantimonate, pancreas perfusion.
The amount of insulin released by the pancreas in response to glucose, as well as its secretory pattern, is closely related to the magnitude and duration of the stimulus [1].

The B cell ensures the accuracy of coupling between stimulus and response, switching on a series of coordinated and sequential intracellular signals. Among these signals, the availability of cytoplasmic calcium plays an important role [2-4]. Influx and efflux of the cation across the cell membrane were soon identified as the main regulators of intracellular concentration [5-8]. However, it has been demonstrated recently that factors other than plasma membrane transport can also modify cellular calcium concentration. In this respect, electron microscopic studies, using pyroantimonate for the identification of calcium [9-12] and studies of ${ }^{45} \mathrm{Ca}^{++}$ uptake by subcellular fractions [13, 14], have demonstrated that several cell organelles (mitochondria, Golgi complex, secretory granules) can regulate free calcium availability by releasing or binding the cation.

Consequently, it has been suggested that these organelles represent exchangeable calcium pools involved in the control of stimulus-secretion coupling.
However, the degree of contribution of each organellepool to the control of cytoplasmic calcium, as well as the possibility that this calcium supply might change according to the glucose-induced insulin secretory phase considered, still remain to be elucidated.

In an attempt to characterize further the calcium distribution within the $\mathrm{B}$ cell and the dynamic changes observed under stimulus with high glucose concentrations, the present experiments were undertaken. Using a combination of ultracytochemical detection of calcium and its quantification by morphometric techniques, we studied both hormone release and cation localization within the $\mathrm{B}$ cell at different times after the beginning of a glucose stimulus in perfused rat pancreas preparations.

\section{Material and methods}

\section{Pancreas perfusion}

Fed female Wistar rats, weighing $180-200 \mathrm{~g}$, were anaesthetized with sodium pentobarbital ( $48 \mathrm{mg} / \mathrm{kg}$, IP). After partial laparotomy, the pancreatic vessels to spleen, stomach, duodenum, colon and small in- 


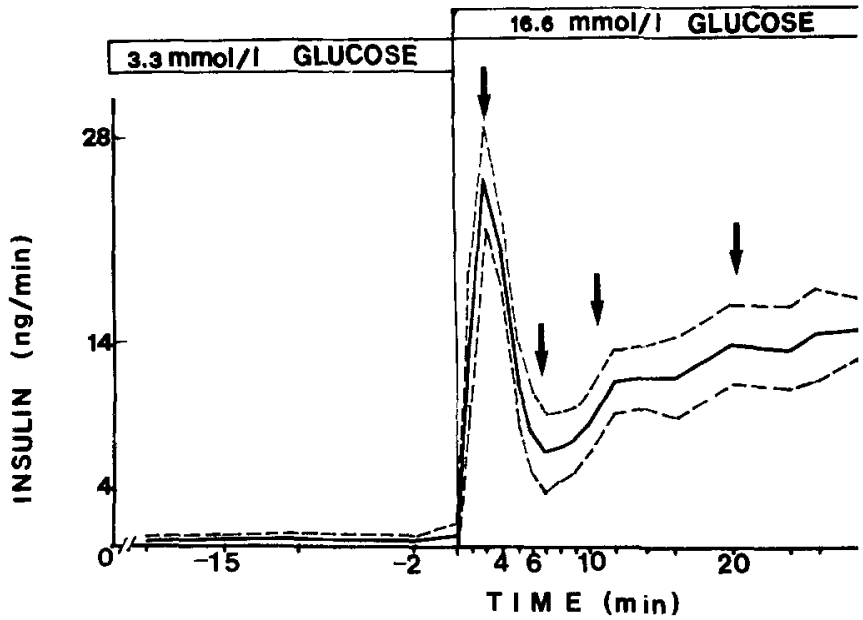

Fig. 1. Glucose-induced insulin release by the perfused rat pancreas preparation. After 20 -min perfusion with low glucose concentration $(3.3 \mathrm{mmol} / \mathrm{l})$ it was challenged with $16.6 \mathrm{mmol} / 1$ glucose concentration. Tissue samples for ultrastructural studies were obtained at timepoints indicated by arrows. Mean \pm SEM secretion rates of six experiments are represented

testine were ligated, together with both renal arteries. The whole organ was perfused as described previously [15]. The perfusate consisted of a Krebs-Ringer bicarbonate buffer containing $\mathrm{CO}_{3} \mathrm{H}^{-}(25 \mathrm{mmol} / 1$, $\mathrm{pH}$ 7.4) supplemented with $0.5 \%$ bovine serum albumin and $4 \% \mathrm{dex}-$ tran, being continuously stabilized with a gas mixture of $5 \% \mathrm{CO}_{2}: 95 \%$ $\mathrm{O}_{2}$. Basal insulin secretion was determined after $20 \mathrm{~min}$ in the pres- ence of $3.3 \mathrm{mmol} / 1$ glucose. A concentrated solution was then added by a side arm infusion pump (Sage Instruments, Orion, Cambridge, Massachusetts, USA) to deliver a $16.6 \mathrm{mmol} / 1$ glucose concentration in the perfusate. After a single passage through the pancreas, the perfusate was collected from the cannulated portal vein into chilled tubes containing $\mathrm{Na}_{2}$ EDTA and kept at $-20^{\circ} \mathrm{C}$. Insulin levels were determined by the dextran-charcoal method [16]

\section{Ultracytochemical calcium distribution in B cells}

Specific time-points were selected to study calcium distribution during the biphasic release of insulin (Fig. 1). They correspond to the apex of the first phase, to the refractory period, and to 10 and $20 \mathrm{~min}$ after the beginning of the $16.6 \mathrm{mmol} / 1$ glucose stimulus during the second phase. Four pancreases were studied at each selected timepoint. Control pancreases perfused with $3.3 \mathrm{mmol} / 1$ glucose were matched for each period.

Calcium localization in B cells was assessed by the pyroantimonate precipitation technique [12]. For this purpose, at the end of the chosen period, the perfusate was switched immediately to a fixative solution consisting of $1.25 \%$ glutaraldehyde and $2.5 \%$ potassium pyroantimonate, adjusted to $\mathrm{pH} 7.3$ with $0.01 \mathrm{~N}$ acetic acid. The tail portions of the pancreases were post-fixed for $1 \mathrm{~h}$ in a solution of $1 \%$ osmium tetroxide and $2.5 \%$ potassium pyroantimonate $(\mathrm{pH} 7.3)$ and washed twice in $7 \%$ sucrose. The material was embedded in Maraglas 655 (Serva Feinbiochemica, Heidelberg, FRG) and thin sections were stained with uranyl acetate and lead citrate for electron microscopy.

The specificity of the pyroantimonate precipitates for calcium were assessed by their disappearance from ultra-thin selections of islets incubated with or without EGTA $(10 \mathrm{mmol} / \mathrm{l})$ for $6 \mathrm{~h}$ at $60^{\circ} \mathrm{C}$ [11].

Quantitative evaluation of the number of calcium pyroantimonate precipitates (CPP) associated with plasma membrane, mitochondria,
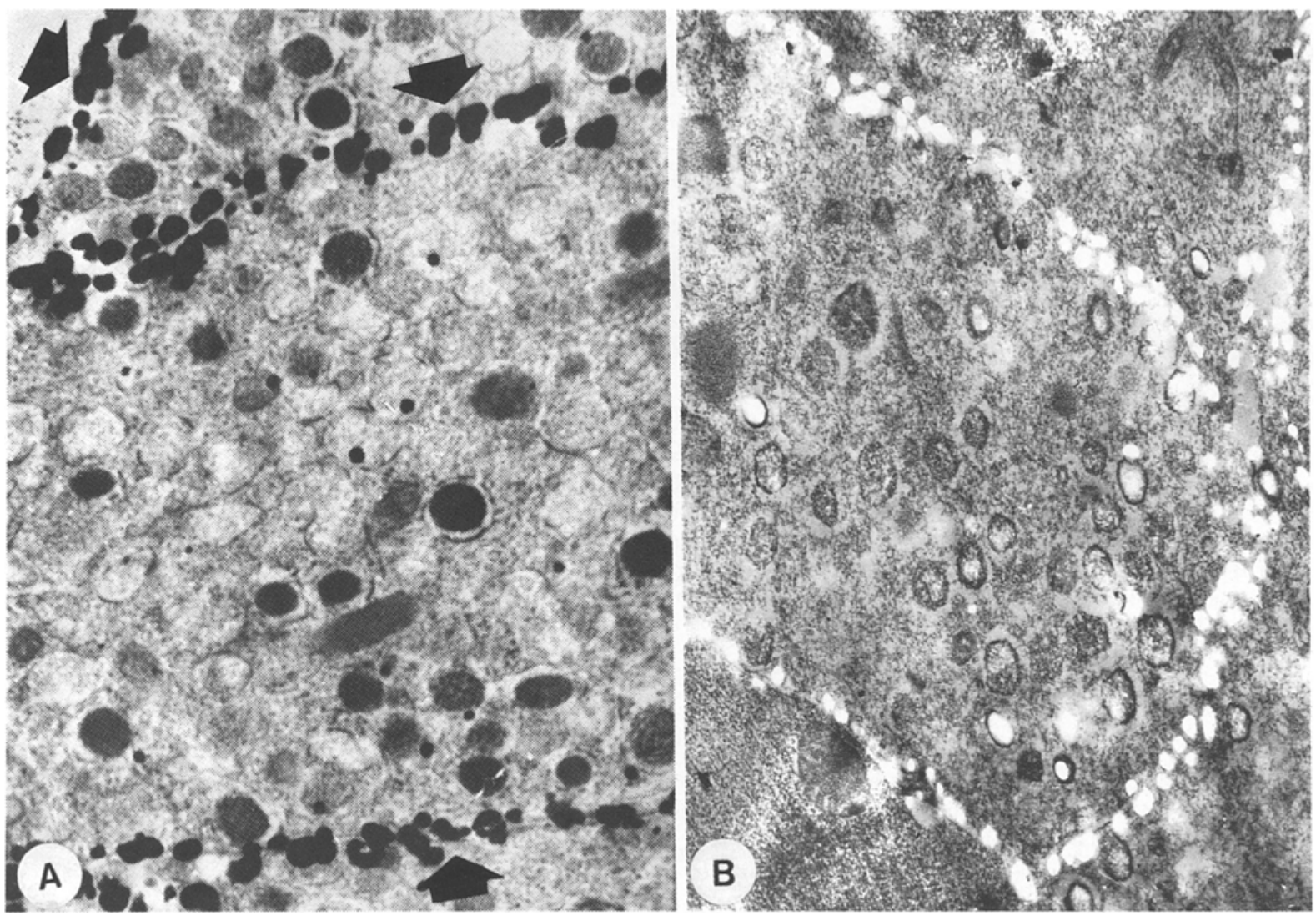

Fig. $2 \mathrm{~A}$ and B. B cells obtained from a pancreas perfused with $16.6 \mathrm{mmol} / \mathrm{l}$ glucose showing A calcium pyroantimonate precipitates mainly attached to the plasma membranes and B calcium precipitates disappear after incubation of the sections with $10 \mathrm{mmol} / 1 \mathrm{EGTA}(\times 26,000)$ 

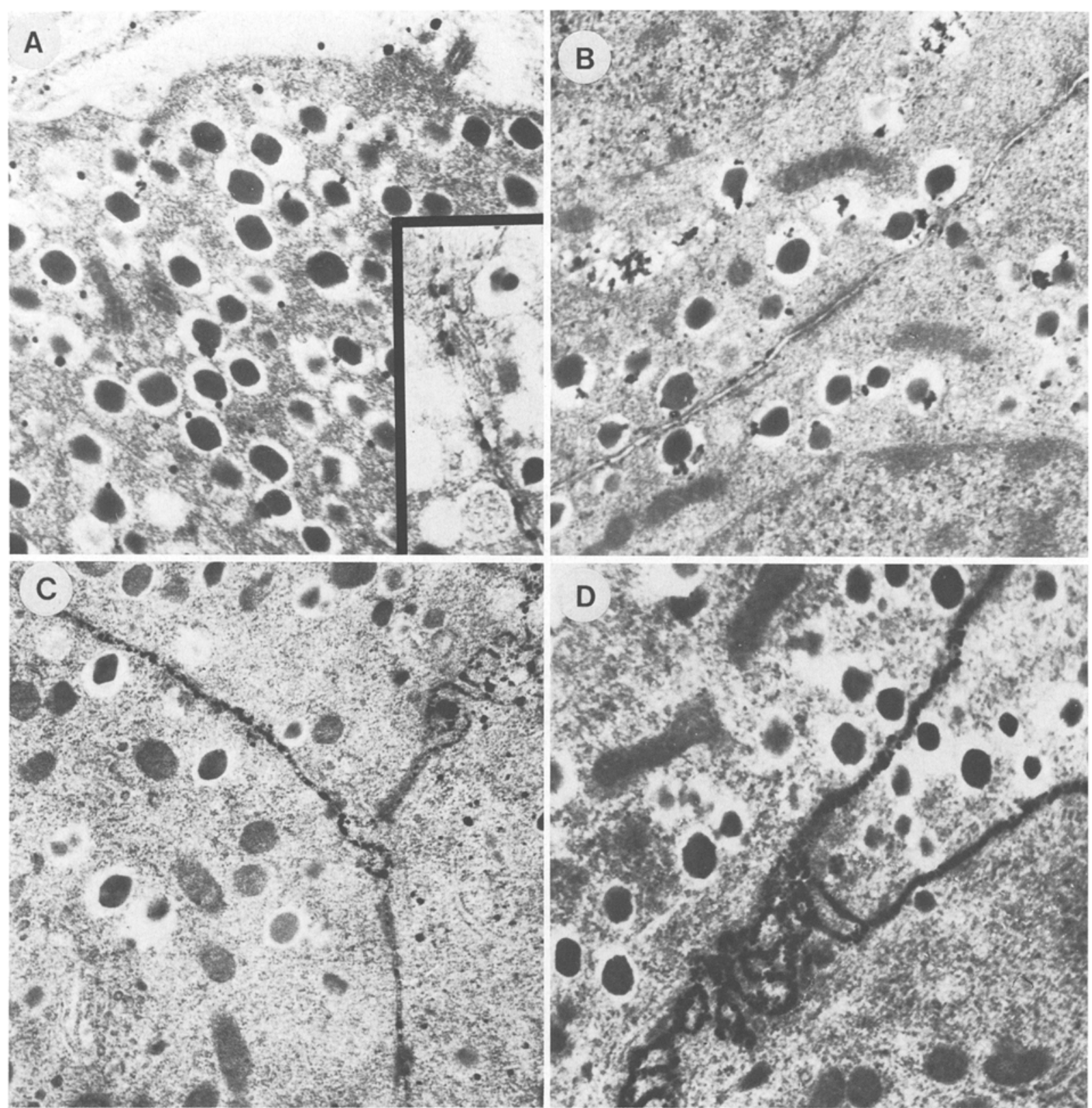

Fig. 3. A A B cell obtained from a pancreas perfused with $16.6 \mathrm{mmol} / 1$ glucose at the apex of the first phase of insulin secretion. Calcium precipitates are scarce and specially located as single grains in the clear halo of the B granules $(\times 26,000)$. Inset: notice CPP at the membrane. B A B cell from a pancreas perfused with $16.6 \mathrm{mmol} / 1$ glucose obtained during the refractory period of insulin secretion. A moderate number of calcium pyroantimonate grains with an irregular aspect are observed on the granules and cell organelles. Few precipitates are attached to the plasma membrane $(\times 26,000)$. C Material obtained from a pancreas perfused with $16.6 \mathrm{mmol} / 1$ glucose during the second phase $10 \mathrm{~min}$ after the start of the glucose stimulus. A moderate number of calcium precipitates are bound to the B cell plasma membranes $(\times 26,000)$. D Perfusion with $16.6 \mathrm{mmol} / \mathrm{l}$ glucose. B cells were obtained at the second phase, $20 \mathrm{~min}$ after the start of the stimulus. A large number of calcium pyroantimonate grains are localized at the level of the plasma membranes $(\times 32,500)$. $\mathbf{E}$ (see opposite) $\mathbf{B}$ cells were studied at the same time-point as in $\mathbf{D}$, but in a pancreas perfused with $3.3 \mathrm{mmol} / 1$ glucose. Calcium precipitates also appear attached to the plasma membranes, but are in smaller number than in $\mathbf{C}(\times 32,500)$

secretory granules, Golgi complex and cytoplasmic matrix was performed, using a reticulum with $1.5 \mathrm{~mm}$ points lattice super-imposed on micrographs obtained under similar magnification $(\times 32,500)$. The results are expressed as the number of coincidences between points of the grid (reticulum) with the CPP. No less than 100 micrographs from four islets obtained from different animals were used at every study period.

Statistical significance was assessed using the Student's t-test.

\section{Results}

\section{Insulin secretion by the perfused pancreas}

Figure 1 shows the biphasic pattern of insulin secretion obtained in a rat pancreas perfused with a sequence of 3.3 and $16.6 \mathrm{mmol} / 1$ glucose. 


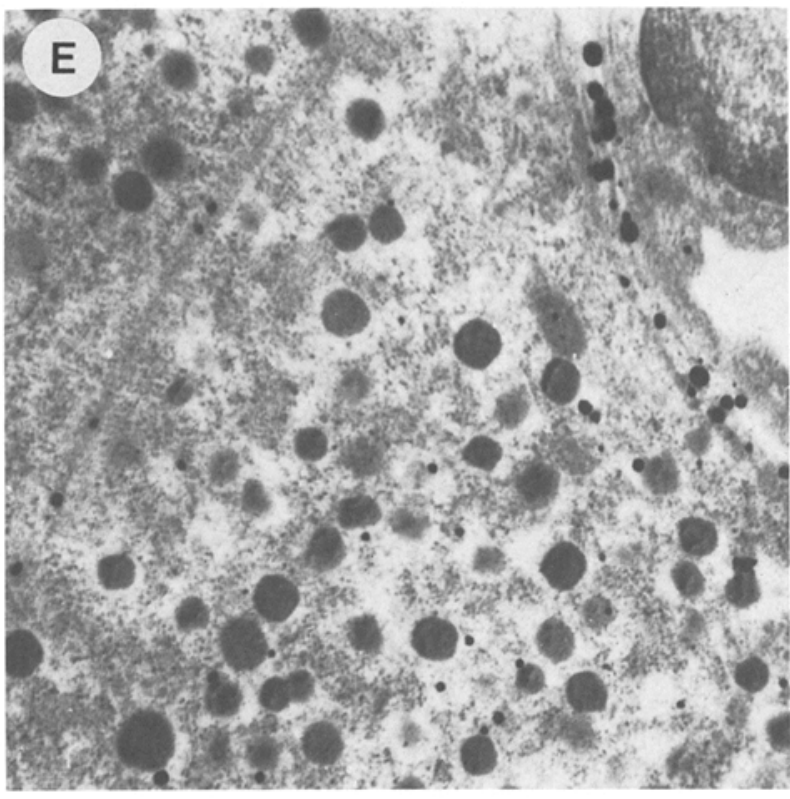

Specificity of calcium pyroantimonate precipitates

The pancreas perfused with pyroantimonate showed roundish well-defined calcium precipitates located at the plasma membrane of a B cell (Fig. 2A). The specificity for calcium of these pyroantimonate precipitates was demonstrated by their disappearance following the incubation of ultra-thin sections of an islet with $10 \mathrm{mmol} / 1$ EGTA during $6 \mathrm{~h}$ at $60^{\circ} \mathrm{C}$ (Fig. $2 \mathrm{~B}$ ). When a similar incubation procedure was performed in the absence of EGTA, no changes were observed in CPP.

\section{Distribution of CPP in B cells during the biphasic process} of insulin secretion

When the pancreases perfused with $3.3 \mathrm{mmol} / 1$ glucose were fixed at the apex of the first phase of insulin secre- tion, only a few CPP were detected, located mainly as single and well-defined grains in the clear halo of the secretory granules.

The CPP presented an identical aspect and distribution when the pancreases were perfused with $16.6 \mathrm{mmol} / 1$ instead of $3.3 \mathrm{mmol} / 1$ glucose. However, in this case the number of grains was significantly greater than those appearing in the presence of low glucose stimulus (Fig. 3 A).

A different pattern of CPP was obtained when the pancreases perfused with $16.6 \mathrm{mmol} / 1$ glucose were fixed during the refractory period. In this case, a moderate number of CPP with irregular aspects were observed on the secretory granules and cell organelles (Fig. $3 \mathrm{~B}$ ). A few precipitates attached to the plasma membrane were also identified.

Pancreas fixed $10 \mathrm{~min}$ after the start of the $16.6 \mathrm{mmol} / 1$ glucose stimulus, showed once again a completely different distribution of CPP. In this case, they were mainly localized at the plasma membrane level (Fig. 3C). A similar distribution, but with a significant increment in the number of CPP, was obtained when pancreases were fixed at $20 \mathrm{~min}$ in the second phase of $16.6 \mathrm{mmol} / \mathrm{l}$ glucose-induced insulin secretion (Fig. 3D). When B cells were fixed at this time-point, but in the presence of $3.3 \mathrm{mmol} / 1$ glucose, a smaller number of CPP appeared attached to the plasma membrane (Fig. $3 \mathrm{E}$ ).

\section{Quantification of CPP}

Table 1 shows the number of precipitates bound to each $B$ cell organelle as a function of time. It can be seen that the total number of precipitates within the B cells shows a time-course increment in both the presence of $3.3 \mathrm{mmol} / \mathrm{l}$ and $16.6 \mathrm{mmol} / \mathrm{l}$ glucose. However, the increment obtained in the presence of the high glucose

Table 1. Intracellular calcium distribution: number of precipitates bound to each B cell organelle

\begin{tabular}{|c|c|c|c|c|c|}
\hline Organelle & $\begin{array}{l}\text { Glucose } \\
(\mathrm{mmol} / \mathrm{l})\end{array}$ & $\begin{array}{l}\text { First phase } \\
\text { (maximum) }\end{array}$ & $\begin{array}{l}\text { Refractory } \\
\text { period }\end{array}$ & \multicolumn{2}{|c|}{ Second phase } \\
\hline Total calcium & $\begin{array}{r}3.3 \\
16.6\end{array}$ & $\begin{array}{l}16.4 \pm 1.4 \\
28.2 \pm 1.5\end{array}$ & $\begin{array}{l}20.8 \pm 2.1 \\
68.5 \pm 4.7\end{array}$ & $\begin{array}{l}29.6 \pm 1.8 \\
80.3 \pm 5.2\end{array}$ & $\begin{array}{r}39.7 \pm 2.6 \\
118.1 \pm 9.1\end{array}$ \\
\hline Cytoplasm & $\begin{array}{r}3.3 \\
16.6\end{array}$ & $\begin{array}{l}3.6 \pm 0.5 \\
5.4 \pm 0.5\end{array}$ & $\begin{array}{r}4.8 \pm 0.9 \\
16.2 \pm 1.1\end{array}$ & $\begin{array}{r}5.9 \pm 0.5 \\
13.6 \pm 1.8\end{array}$ & $\begin{array}{l}3.8 \pm 0.4 \\
7.2 \pm 1.5\end{array}$ \\
\hline Granule & $\begin{array}{r}3.3 \\
16.6\end{array}$ & $\begin{array}{r}7.9 \pm 0.7 \\
13.5 \pm 0.8\end{array}$ & $\begin{array}{r}8.5 \pm 1.2 \\
26.7 \pm 1.5\end{array}$ & $\begin{array}{l}13.5 \pm 0.8 \\
21.8 \pm 1.6\end{array}$ & $\begin{array}{l}13.5 \pm 0.7 \\
13.6 \pm 1.9\end{array}$ \\
\hline Mitochondria & $\begin{array}{r}3.3 \\
16.6\end{array}$ & $\begin{array}{l}1.7 \pm 0.2 \\
2.9 \pm 0.3\end{array}$ & $\begin{array}{l}1.7 \pm 0.3 \\
5.3 \pm 0.4\end{array}$ & $\begin{array}{l}2.0 \pm 0.5 \\
6.0 \pm 0.7\end{array}$ & $\begin{array}{r}2.0 \pm 0.3 \\
18.5 \pm 2.8\end{array}$ \\
\hline Golgi complex & $\begin{array}{r}3.3 \\
16.6\end{array}$ & $\begin{array}{l}0.4 \pm 0.2 \\
0.6 \pm 0.1\end{array}$ & $\begin{array}{l}0.8 \pm 0.2 \\
2.3 \pm 0.6\end{array}$ & $\begin{array}{l}0.1 \pm 0.1 \\
1.3 \pm 0.4\end{array}$ & $\begin{array}{l}0.5 \pm 0.1 \\
1.5 \pm 0.5\end{array}$ \\
\hline
\end{tabular}

Each value represents the mean \pm SEM of the coincidence between the points of the grid and the calcium precipitates. They are expressed as a function of time and glucose concentration in the medium 


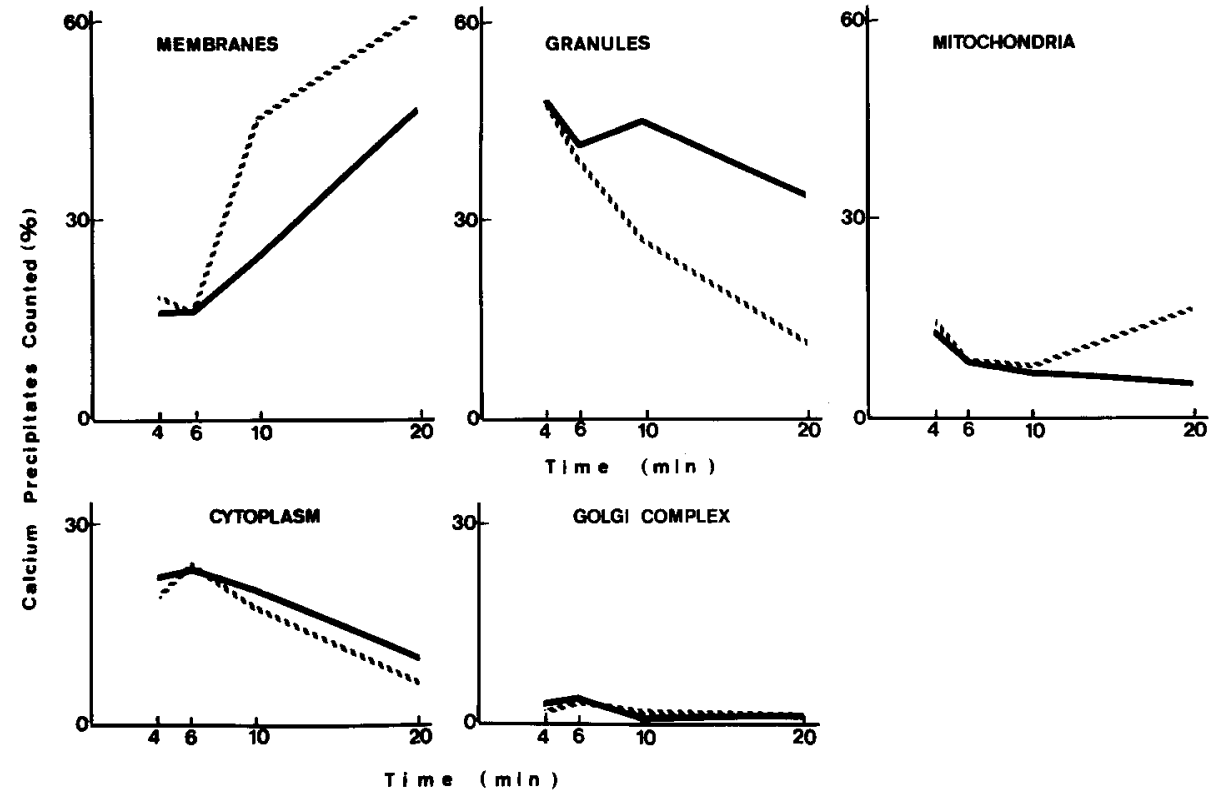

Fig.4. Calcium grains distribution in B cell organelles expressed as a percentage of the total number of calcium precipitates counted at the various time-points studied with glucose at $3.3 \mathrm{mmol} / 1(-)$ and $16.6 \mathrm{mmol} / 1(\cdots)$ concentrations concentration was significantly higher at every timepoint than that observed at the low glucose concentration. On the other hand, neither the number of CPP nor their time-course behaviour were the same in all B cell organelles.

CPP showed a slow and progressive increment both in plasma membrane and mitochondria. On the other hand, in the cytoplasm, B granules and Golgi complex, a sharp increase was detected in the number of CPP during the refractory period, followed by a slow and continuous decrease until the end of the experiment.

These results have been expressed as a percentage of the total number of CPP counted (Fig. 4). Using this expression, it can be seen that the greatest changes in the number of CPP were obtained in those attached to the plasma membrane and the $B$ granules, with little change observed in the other organelles. In addition, it seems that while most of the CPP are bound to the granules during the first phase, they appear to be attached to the plasma membrane during the second phase. However, during the refractory period, CPP remain bound to B granules, cytoplasmic matrix and plasma membranes.

\section{Discussion}

Several authors have taken advantage of the pyroantimonate technique to identify intracellular cation localization $[17,18]$. When applied to the endocrine pancreas, other researchers were able to localize CPP bound to different islet cell organelles [9-12]. The specificity of these CPP was demonstrated using either Xray microprobe analysis or their disappearance in the presence of EGTA [11]. The latter procedure was adopted in the present investigation.

Using this ultracytochemical method, we have confirmed the presence of CPP attached to different B cell organelles $[9-12,19]$. The total number of these precipitates was increased as a function of time and glucose concentration in the perfusion medium. The shape of the curve representing the total number of CPP was similar to that obtained by measuring the intracellular calcium content in isolated islets [20].

It is interesting to note that changes in calcium distribution within the B cells were detected shortly after the beginning of the $16.6 \mathrm{mmol} / 1$ glucose stimulus.

As has been described in the Results section, the CPP bound to every B cell organelle were not identical in their absolute or relative number or in the timedependent distribution.

Accordingly, CPP appeared to be bound differently to $\mathrm{B}$ cell organelles during the first phase, the refractory period and the second phase of insulin secretion. While most of the CPP were preferently bound to secretory granules during the first phase, their number gradually increased at the plasma membrane level during the second phase.

Using the isolated perfused rat pancreas and the pyroantimonate precipitation technique, Klöppel and Bomer [12] studied the effect of low and high glucose concentrations upon calcium distribution in B cells. They have also described the existence of CPP bound to plasma membrane, secretory granules, mitochondria, cytoplasma and nucleus. Immediately after the start of a $20 \mathrm{mmol} / 1$ glucose stimulus, they showed a significant increment in the number of CPP confined at the plasma membrane level. Conversely in our experiments, we detected significant increments, though of variable magnitude, in all the organelles studied. This apparent discrepancy could probably be ascribed to the different sampling schedule used. We collected data from both the apex of the first phase of insulin secretion and the refractory period, while these two phases were combined in their report [12]. It is clear that in our experi- 
ments the number of CPP at every organelle was significantly different in both periods . Consequently, it would be unreasonable to make a straight comparison between the data reported by Klöppel and Bomer [12] and the present results.

However, at the late second phase of high glucose concentration stimulus, both studies showed an increment in the number of CPP bound to every B cell organelle. On the other hand, due to the frequency of the sampling schedule used in our study, the dynamic nature of these different CPP-pools bound to each organelle can be identified and properly related to a secretory phase of glucose-induced insulin secretion.

Assuming that the final steps in the process of glucose-induced insulin secretion are triggered mainly by the availability of free calcium in the cytoplasm, the changes in the distribution of CPP might indicate that such availability depends on its release from several readily exchangeable pools. The importance of these intracellular calcium pools might be relevant since the actual free calcium pool in the cytosol is less than $0.1 \%$ of the total calcium [4]. This being the case, our experimental design cannot offer a clear explanation for the coupling mechanism between changes in glucose concentration and the driving forces that bind calcium to one or another organelles.

Sugden and Ashcroft reported that the mitochondrial fraction isolated from rat islets actively incorporates ${ }^{45} \mathrm{Ca}^{++}$, and this uptake is modified by some glucose metabolite, probably phosphoenolpyruvate [14]. Similar results were obtained by other authors using preloading of intact islets with ${ }^{45} \mathrm{Ca}^{++}$and subsequent isolation of subcellular fractions [21]. Consequently, a similar hypothesis could explain the changes observed in our experiments regarding the mitochondrial CPP during insulin secretion elicited by glucose.

The participation of secretory granules as dynamic stores of calcium in the regulation of the process of exocytosis in isolated islets has been reported previously [20-22] and also in the perfused bovine adrenal gland [23]. This calcium uptake by secretory granules could be coupled with a proton exchange $[24,25]$.

Calcium binding to plasma membranes has also been reported by other authors $[13,22,26]$ and related to the control of the intracellular cation availability. The mechanism of this uptake has been ascribed to the presence of a $\left(\mathrm{Ca}^{++}-\mathrm{Mg}^{++}\right)$-ATPase activity in the plasma membrane [27]. It was suggested that localization of calcium at the B granules and plasma membrane level might also neutralize repulsive electrostatic forces during exocytosis $[28,29]$.

We are aware of criticism concerning the usefulness of the pyroantimonate precipitation technique in the study of intracellular calcium distribution. However, the real value of this method in comparative studies (we compare non-stimulated versus stimulated B cells) is accepted even in the most critical review [30]. Moreover, the reproducibility and small dispersion of the recorded data, the clear dependence of the calcium pyroantimonate grains distribution with both glucose concentrations employed and time of perfusion, as well as the close correlation between our data and those obtained by different experimental approaches, such as intracellular calcium content [20], play against an artefactual or randomized effect.

We feel our results provide additional support for the concept that intracellular readily exchangeable pools are regulators of calcium availability for the process of glucose-induced insulin secretion. However, further evidence must be obtained to clarify the underlying mechanism or mechanisms that regulate intracellular calcium distribution.

Acknowledgments. The authors wish to thank Dr. R. Gutman for providing the anti-insulin serum for radioimmunoassay, Mrs. E.P.A.Gagliardino for the illustrations, Mrs. A. M. Yashan for technical help in the immunoassay and Mrs. S. Rivas and Mr. A. Budzvicky for technical assistance in electron microscopy. We are also indebted to Mrs. S. Urquiola for secretarial support. This work was partially supported by funds from CONICET, CIC Pcia. de Buenos Aites and SUBCYT from Argentina. These results were presented partially at the 11th Congress of the International Diabetes Federation held in Nairobi, Kenya in November 1982. JJg, ORR and MCS are members of the Carrera del Investigador CONICET; CLGD and REH are members of the Carrera del Investigador CICPBA.

\section{References}

1. Grodsky GM, Curry D, Landahl H, Bennet L (1969) Further studies on the dynamic aspects of insulin release in vitro with evidence for a two compartmental storage system. Acta Diabetol lat 6 (Suppl 1): 554-579

2. Malaisse WJ, Herchuelz A, Devis G, Somers G, Boschero AC, Hutton JC, Kawazu S, Sener A, Atwater IJ, Duncan G, Ribalet B, Rojas G (1978) Regulation of calcium fluxes and their regulatory roles in pancreatic islets, Ann NY Acad Sci 307: 562-582

3. Kohnert KD, Hahn HJ, Gylfe E, Borg H, Hellman B (1979) Calcium and pancreatic B cell function. 6. Glucose and intracellular ${ }^{45} \mathrm{Ca}$ distribution. Mol Cell Endocrinol 16: 205-220

4. Wollheim BC, Sharp GW (1981) Regulation of insulin release by calcium. Physiol Rev 61: 914-173

5. Malaisse-Lagae F, Malaisse WJ (1971) The stimulus secretion coupling of glucose-induced insulin release. III. Uptake of calcium by isolated islets of Langerhans. Endocrinology 88:72-80

6. Hellman B, Lenzen S, Sehlin J, Taljedal IB (1977) Effects of various modifiers of insulin release on the lanthanum-non-displaceable ${ }^{45} \mathrm{Ca}^{2+}$ uptake by isolated pancreatic islets. Diabetologia 13 : 49-53

7. Malaisse WJ, Brisson GR, Baird LE (1973) Stimulus-secretion coupling of glucose-induced insulin release. X. Effect of glucose on ${ }^{45} \mathrm{Ca}$ efflux from perifused islets. Am J Physiol 224: 389-394

8. Kikuchi M, Wollheim BC, Cuendet GS, Renold AR, Sharp GW (1978) Studies on the dual effects of glucose on ${ }^{45} \mathrm{Ca}^{2+}$ efflux from isolated rat islets. Endocrinology 102: 1339-1349

9. Herman L, Sato T, Hales CN (1973) The electron microscopic localization of cations to pancreatic islets of Langerhans and their possible role in insulin secretion. J Ultr Res 42: 298-311

10. Schäffer HJ, Klöppel G (1974) The significance of calcium in insulin secretion. Ultrastructural studies on identification and localization of calcium in activated and inactivated B cells in mice. Virchows Arch A Pathol Anat Histol 362: 231-245

11. Ravazzola M, Malaisse-Lagae F, Amherdt M, Perrelet A, Malaisse 
WJ, Orci L (1976) Patterns of calcium localization in pancreatic endocrine cells. J Cell Sci 27: 107-117

12. Klöppel G, Bomer G (1979) Ultracytochemical calcium distribution in B cells in relation to biphasic glucose-stimulated insulin release by the perfused rat pancreas. Diabetes $28: 585-592$

13. Howell SL, Montague W, Tyhurst M (1975) Calcium distribution in islets of Langerhans: a study of calcium concentrations and of calcium accumulation in B cell organelles. J Cell Sci 19:395-409

14. Sugden MC, Ashcroft SJH (1978) Effects of phosphoenolpyruvate, other glycolytic intermediates and methylxantines on calcium uptake by mitochondrial fraction from rat pancreatic islets. Diabetologia 15: 173-180

15. Rebolledo OR, Hernández RE, Zanetta AC, Gagliardino JJ (1978) Insulin secretion during acid-base alterations. Am J Physiol 234: E426-429

16. Herbert V, Lau KS, Gottlieb CHW, Bleicher SJ (1965) Coatedcharcoal immunoassay of insulin. J Clin Endocrinol Metab 25: $1375 \cdots 1384$

17. Kommick H (1962) Elektronenmikroskopische Lokalisation von $\mathrm{Na}^{+}$und $\mathrm{Cl}^{-}$in Zellen und Geweben. Protoplasma 55: 414-432

18. Simson JAV, Spicer SS (1975) Selective subcellular localization of cations with variance of the potassium (pyro)antimonate technique. J Histochem Cytochem 23: 575-598

19. Gagliardino JJ (1983) Concurrent factors in the regulation of insulin secretion. In: EC Mngola (ed) Diabetes 1982. Excerpta Medica, Amsterdam, pp 19-27

20. Andersson T, Betsholtz CH, Hellman B (1982) Granular calcium exchange in glucose-stimulated pancreatic B-cells. Biomedical Res 3: 29-36

21. Andersson T, Berggren PO, Gylfe E, Hellman B (1982) Amounts and distribution of intracellular magnesium and calcium in pancreatic B-cells. Acta Physiol Scand 114: 235-241

22. Hellman B, Abrahamson H, Andersson T, Berggren PO, Flatt $P$, Gylfe E, Hahn HJ (1980) Calcium movements in relation to glucose-stimulated insulin secretion. Horm Metab Res Suppl Series $10: 122-130$
23. Serck-Hansen G, Christiansen EN (1973) Uptake of calcium in chromaffin granules of bovine adrenal medulla stimulated in vitro. Biochem Biophys Acta 307: 404-414

24. Abrahamson H, Gylfe E (1980) Demonstration of a proton gradient across the insulin granule membrane. Acta Physiol Scand 109: 113-114

25. Abrahamson H, Gylfe E, Hellman B (1981) Influence of external calcium ions on labelled calcium efflux from pancreatic B-cells and insulin granules in mice. J Physiol 331: 541-550

26. Borowitz JL, Mathews EK (1980) Calcium exchangeability in subcellular fraction of pancreatic islets. J Cell Sci 41: 233-243

27. Pershadsingh HA, McDaniel ML, Landt M, Bry CHG, Lacy PE, McDonald JM (1980) $\mathrm{Ca}^{2+}$-activated ATPase and ATP-dependent calmodulin-stimulated $\mathrm{Ca}^{2+}$ transport in islet cell plasma membrane. Nature 288: 492-495

28. Dean PM, Mathews EK (1970) Electrical activity in pancreatic islets cells: effects of ions. J Physiol 210: 265-275

29. Dean PM (1974) Surface electrostatic-charge measurements on islets and zymogen granules: effect of calcium ions. Diabetologia $10: 427-430$

30. Morgan AJ (1979) Non-freezing techniques of preparing biological specimens for electron microprobe X-ray microanalysis. Scan Electron Micr 2: 635-648

Received: 20 May 1983

and in revised form: 12 December 1983

Dr. Juan José Gagliardino

CENEXA

Facultad de Ciencias Médicas-UNLP

Calle 60 y 120

(1900) La Plata

Argentina 